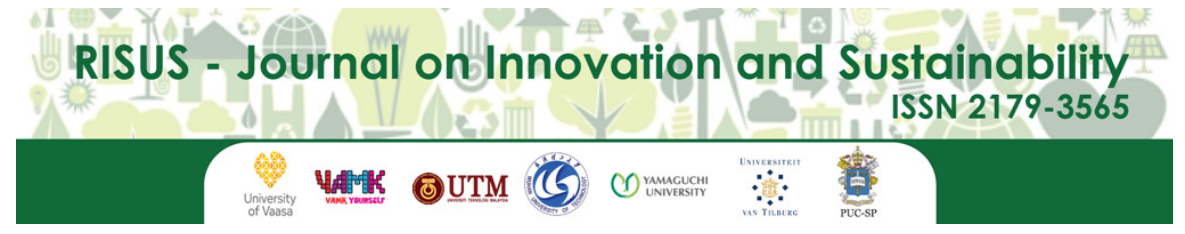

RISUS - Journal on Innovation and Sustainability volume 8, número 4 - 2017

ISSN: 2179-3565

Editor Científico: Arnoldo José de Hoyos Guevara Editora Assistente: Lívia Lopes Aguiar

Avaliação: Melhores práticas editoriais da ANPAD

\title{
ECOSOCIAL INNOVATIONS AS PART OF SOCIAL AND SOLIDARITY ECONOMY: LOCAL MODELS FOR A SUSTAINABLE DEVELOPMENT
}

\author{
Inovações Eco-sociais como Parte da Economia Social e Solidária: \\ Modelos Locais Para um Desenvolvimento Sustentável
}

Ingo Peter Stamm, Tuuli Hirvilammi, Aila-Leena Matthies, Kati Närhi University of Jyvaskyla, Kokkola University Consortium Chydenius, Finland

E-mail: Ingo.Stamm@chydenius.fi; Tuuli.Hirvilammi@chydenius.fi; aila-leena.matthies@chydenius.fi; kati.narhi@jyu.fi

\begin{abstract}
The paper first introduces the concept of ecosocial innovations. These are local organizations embedded in social and solidarity economy, which combine ecological and social challenges in their work. They are successful models of how to operationalize sustainability. Based on a cross-national, multi-case study with a social work background, the paper aims at providing insights about the work and significance of ecosocial innovations. Drawn from interview material collected in four countries within selected ecosocial innovations, seven themes as common characteristics of these local actors are presented. One trait of ecosocial innovations is a creative mix of paid work, voluntary engagement, and subsidized employment in their activities. This mix is not only a compromise due to a lack of resources, but it also acknowledges the interconnectedness of well-being and sustainable social practices. The paper concludes with a summary of the main results and an outlook of the potential of ecosocial innovations for the future. They could for example serve as models for an ecological social work
\end{abstract}

Keys-Words: Ecosocial innovations, social and solidarity economy, sustainability, social work

Recebido em: 15/09/2017

Aceito em: 24/12/2017 


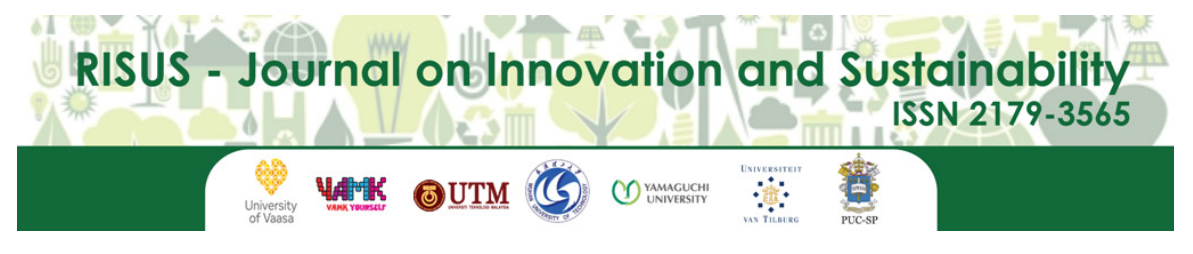

RISUS - Journal on Innovation and Sustainability volume 8, número 4 - 2017

ISSN: $2179-3565$

Editor Científico: Arnoldo José de Hoyos Guevara Editora Assistente: Lívia Lopes Aguiar

Avaliação: Melhores práticas editoriais da ANPAD

\title{
ECOSOCIAL INNOVATIONS AS PART OF SOCIALAND SOLIDARITY ECONOMY: LOCAL MODELS FOR A SUSTAINABLE DEVELOPMENT
}

\author{
Inovações Eco-sociais como Parte da Economia Social e Solidária: \\ Modelos Locais Para um Desenvolvimento Sustentável
}

Ingo Peter Stamm, Tuuli Hirvilammi, Aila-Leena Matthies, Kati Närhi University of Jyvaskyla, Kokkola University Consortium Chydenius, Finland

E-mail: Ingo.Stamm@chydenius.fi; Tuuli.Hirvilammi@chydenius.fi; aila-leena.matthies@chydenius.fi; kati.narhi@jyu.fi

\begin{abstract}
Resumo: Este artigo apresenta o conceito de inovações eco-sociais. Conceito que remete para as organizações locais ligadas à economia social e solidária cuja intervenção não deixa de atender aos desafios sociais e ecológicos, podendo ser vistos como modelos de sucesso na operacionalização da sustentabilidade. Baseado num estudo comparativo multi-caso internacional, a partir de uma abordagem do Serviço Social, o artigo procura mostrar o trabalho desenvolvido nestas iniciativas, salientando a importância das mesmas. Entrevistas recolhidas junto dos atores locais em quatro países permitiram identificar sete características comuns às diferentes experiências estudadas. Destaca-se a identificação de um padrão comum no funcionamento destas inovações eco-sociais: uma criativa fusão de trabalho assalariado, voluntariado e emprego subvencionado. Esta combinação não é resultado, apenas, de compromissos motivados pela falta recursos, mas, também, da adoção de práticas sociais sustentáveis e de bem-estar. O artigo termina com um resumo das principais conclusões e um sobrevoar do potencial que as inovações eco-sociais apresentam para o futuro, podendo, por exemplo, fornecer modelos para um serviço social ecológico.

Palavras-Chave: Inovações eco-sociais, economia social e solidária, sustentabilidade, serviço social
\end{abstract}

Recebido em: 15/09/2017

Aceito em: 24/12/2017 


\section{INTRODUCTION}

What is the common ground between a mobile bike repair station in Belgium, a field of organic vegetables in South Tyrol, a former hospital in Helsinki hosting cultural events, and an open space for sustainable well-being? They can all be called ecosocial innovations (ESI), which are developing and spreading throughout European societies at the present time. They bring sustainability into the world (Fichter, 2010; Howaldt, Kopp, \& Schwarz, 2015); or in other words, these innovations are the operationalization of a sustainable development (Mehmood \& Parra, 2013). The projects, associations, and cooperatives behind the concrete action are part of a social and solidarity economy that contributes to a change of the current, dominating, economic growth system. Moving toward a sustainable economy means finding ecologically sound and socially fair economic solutions (Jackson, 2009; Gismondi \& Cannon, 2012). The social and solidarity economy already puts some of these solutions into action at the local level. It can be seen as a forerunner or as a counter-economy (Wallimann, 2014, p. 49; Elsen, 2016).

This paper is based on a cross-national, multi-case study that examines existing ecosocial innovations in Europe and their challenges ${ }^{1}$. Social work and its nascent debates on the ecological imperatives of the profession and its role in a sustainable development are the background of the study (cf. Kemp, 2011; Dominelli, 2012, 2014; Coates \& Gray, 2012; Peeters, 2012; McKinnon \& Alston, 2016; Matthies \& Närhi, 2017) ${ }^{2}$. The bedrock of a new ecosocial paradigm in social work and in social policy is to consider environmental problems as social problems, the environmental crisis as a social crisis, and therefore environmental policies as social policies (cf. Wallimann, 2013; Cook, Smith, \& Utting, 2012). Even though the consequences of the environmental crisis can more directly be seen as affecting the most vulnerable people in countries of the global south, the logic stays the same: since human wellbeing is ultimately dependent on healthy ecosystems, the crisis is threatening the basis of welfare systems.

The paper introduces the concept of ecosocial innovation in the context of the social and solidarity economy. It aims to provide knowledge about the social practices and the significance of ecosocial innovations. With case study data, the paper shows how the integrated challenges of sustainability are responded to in the concrete practices of the ecosocial innovations. In short, ecosocial innovations are social innovations with a clear and consistent ecological approach that are improving both social and ecological sustainability. Common definitions of social innovations combine two components: they are establishing and improving social relations and are addressing and satisfying human needs (e.g., Nicholls \& Murdock, 2012; Moulaert, MacCallum, Mehmood, \& Hamdouch, 2013; McNeill, 2013; Nicholls, Simon, \& Gabriel, 2015). Some authors emphasize that social innovations are crucial for empowering people and bringing about social change on a macro level (cf. Moulaert et al., 2013; Mehmood \& Parra 2013). In many studies on social innovations, their potential for a sustainable development is underrated or neglected. The identification of this missing link was the starting point for this study, which consolidates social innovation and sustainability in the concept of ecosocial innovations.

\footnotetext{
${ }^{1}$ It is part of the research project ECOSOS (Contribution of Social Work and Systems of Income Security to the Ecosocial Transformation of Society), which is a 4-year-long research project funded by the Academy of Finland. The project encompasses eight work packages. Further work packages will deal with the role of social work and the impact of ecosocial transition on social security systems.

${ }^{2}$ Närhi and Matthies (2016) present an overview of the diverse traditions of ecological thinking in social work and the various concepts.
} 
The central part of the paper is dedicated to six ecosocial innovations (cases), which are located in Finland, Germany, Belgium, and Italy. For the case studies semi-structured interviews served as the main data source. The paper presents the main results of the thematic analysis of the interview material in seven themes and concludes with delineating commonalities, differences, and relationships between the cases and a brief look at the possible roles of social work in ecosocial innovative action.

\section{THEORETICAL BACKGROUND}

The concept of social innovation is as popular nowadays as it is hard to grasp. Definitions and concepts vary. Its openness can be seen as a weakness as well as a strength. Following the open book of social innovations, they are simply "both good for society and enhance society's capacity to act" (Murray, Caulier-Grice, \& Mulgan 2010, p. 4). Caulier-Grice et al. (2012, pp. 20-21) suggest five core elements of social innovation. They can serve as an orientation when discussing the nature and the outcomes of social innovations: novelty, from ideas to implementation, meets a social need, is effective, and enhances society's capacity to act. Within these general elements one can identify both a broader and a narrower idea of social innovations. The broader idea sees the importance of social innovations also for social entrepreneurship, new forms of organizational management, and the development of better services and programs. The driving actors come from all parts of society and also the state, the private sector, and academia. The narrower view on social innovations emphasizes the bottom-up character and the central traits of participation, democratic decision-making, and self-organization. The main drivers are civil society actors, who often are innovative and pragmatic individuals or small groups of activists. They implement their ideas locally in the field of the social and solidarity economy (SSE).

The social and solidarity economy, like the related concepts of local or community as well as diverse economies (Gibson-Graham, 2008), focuses on the positive aspects of the civil society sector instead of the negative (non-profit) (Elsen \& Schicklinski, 2016). Wallimann (2014, p. 51) suggests a perception of SSE “as a 'grass roots'-based, regionally oriented federation of democratically run 'local' enterprises, whereby networks between federations may be created to cover larger territories. Organized in various legal forms as cooperatives, associations, foundations, or corporations, the important criterion is that all should be organized for members to have control over capital and surplus value". According to Utting (2015, p. 2) SSE gives primacy to social and environmental objectives, recalls the role of ethics in economic activity, and supports active citizenship.

The number of national and cross-national research projects on social innovations in Europe on the concept and the implementation is high, which has resulted in numerous publications, articles, and research reports. Examples are the WILCO project on social innovations for social cohesion (cf. Evers, Ewert, \& Brandsen, 2014), TEPSIE (from 20122015), and TRANSIT (from 2014-2017). The project "Social Innovations and the Environment" is one of the few that uses the term social innovations in the field of environmental policies and its local implementations (Science Communication Unit, 2014). The final report provides short case descriptions in six different European countries and shows the great variety in their forms of action and scope. Among the cases are the International Transition Network and the Copenhagen City Bee Project "bybi". The results demonstrate how the pathways of many social innovations for the environment are different and non-linear as well as how multiple drivers often lead to multi-functional solutions (Science Communication Unit, p. 25). 
However, most projects omit the focus on innovations with an ecological approach and highlight the economic and social dimension. The two streams of social innovation and sustainability hardly ever communicate and therefore remain indifferent to each other (Mehmood \& Parra, 2013). The number of authors linking the two explicitly and emphasizing the transformative potential of social innovations for a sustainable development is only slowly rising (cf. Haxeltine et al., 2013; McNeill, 2013; Parra, 2013; Olson et al., 2017). This leads also to an inconsistent terminology and a missing definition of the concept. Examples are innovations for sustainability (cf. Hargreaves, Longhurst, \& Seyfang, 2012), sustainable innovations, as well as grassroots or niche innovations (for sustainable development) (Seyfang $\&$ Smith, 2007). For more technology-oriented innovations in the context of sustainability, the term green innovations, eco-innovations, or environmental innovations seem to dominate (cf. Schiederig, Tietze, \& Herstatt, 2012; van Kemenade \& Teixeira, 2017). In the context of social work research social innovations promoting ecological sustainability are also not clearly defined or examined, even though they might serve as models for the practical dimension of "ecosocial work". They could work for example as vantage points for community development, as possibilities to enhance sustainable well-being, and as platforms for social action for economic and political change (Boetto 2017, pp. 61-62; Kemp, 2011).

\section{RESEARCH SETTING AND METHODS}

The criteria for ecosocial innovations were defined in the initial phase of the research. They served as guidelines in the mapping phase and for the final selection of the cases. The organizations, associations, cooperatives, or projects had to fulfill the following three criteria:

1.They are innovative by making a significant contribution to a transition toward a more sustainable society. They are part of a social or solidarity economy at the local or grass-roots level and are not (or at least not only) aiming to make a profit.

2.The innovations are realizing new ideas for, by, and with young unemployed people. They enable participation and respect the views and needs of young people.

3.The innovations are improving ecological sustainability. They enhance the fair distribution of material resources and reduce environmental impacts in their own activities and in the communities in which they are situated.

The criteria defined ideal cases and were therefore partly changed in the course of the mapping phase. Especially the second criteria was modified as not enough innovations could be identified that focused only on young unemployed people. Thereafter, the activities of the ESI did not have to aim at a certain age group. 
The researchers systematically used the internet, emails, and social media; activists, researchers from social work and other academic disciplines, social work practitioners, as well as students were contacted and asked for ideas and contact persons. Using the snowball method, information about 48 ESIs in five countries - Finland, Germany, Belgium, Italy, and the UK - were collected. During this phase, the researchers conducted preliminary interviews with several coordinators and participants. Finally, six cases were selected for in-depth case studies: three cases in Finland and one each in Germany, Italy, and Belgium based on their high correspondence with the criteria and in order to show the broad diversity of the found ESI. The main research questions were: what work ecosocial innovations are doing and how do they function? These were backed up by the sub-questions about enabling and hindering structures.

Case study research is sometimes critically viewed as just a label that is stuck on many, very heterogeneous studies (cf. Flyvbjerg, 2006). In social work (Lee, Mishna, \& Brennenstuhl, 2010) and other disciplines, it is increasingly used. The term can be used for both an analysis process and a product of analysis (cf. Stake, 2000; Bazeley, 2013). Case study research can be the preferred method when the main research questions are open questions (Yin, 2014).

In this study the chosen ecosocial innovations are seen as the cases. Following Ragin and Becker's (1992, pp. 1-18) work on case conceptions, the cases were found and made at the same time. They were found because they are empirically real and bounded but specific. They were identified and established as cases by the research team in the course of the described phase of mapping. However, they were also made as cases as specific theoretical constructs. The ecosocial innovations are representative or common cases since they exemplify a broader category of which they are members (for more on different types of cases see Yin, 2014; also Bryman, 2012). As the mapping phase showed, numerous innovations (cases) with quite similar approaches are emerging in European countries.

This multi-case study is exploratory and descriptive in nature. Not only were a number of cases chosen, but they were chosen from four different countries. Therefore, the study at hand is a cross-national, multi-case study with comparative elements. The challenge of conducting cross-national research was undertaken in order to identify differences and similarities in a phenomenon that can clearly be observed in many countries. Still, the aim was not a direct comparison but to try to understand the functioning of ecosocial innovations better and to have the chance to find more diverse and interesting cases. By examining the special character of each ESI based on national social welfare settings, the countries can be seen as second-tier cases.

As with any case study research, a crucial step is defining the cases (here the ecosocial innovations) as the units of analysis. One trait of each case study is the use of a variety of methods or "multiple sources of evidence" (Yin, 2014, p. 17), which enables a triangulation of data (Lee et al., 2010, p. 686; see Flick, 2012 on triangulation). This can mean a mix of quantitative and qualitative methods or the use of different qualitative methods. The latter way was chosen for this study since qualitative methods are most useful for understanding the concrete practices and the significance of the small sample of chosen ecosocial innovations. 
Altogether, 28 semi-structured individual interviews as well as two group interviews with narrative elements were conducted. The interviews were the main method used to examine the cases. The interviewees were founders, coordinators, participants, and users. Altogether, 17 female and 18 male adults from various age groups were interviewed; 28 persons were interviewed individually, and seven took part in group interviews. In Italy, South Tyrol, the interview language was German. In Belgium the interviews took place in English, and some parts were directly translated from Dutch into English during the interview by other employees of the ESI. In Germany and Finland the mother tongues of German and Finnish were used. In addition to the interview data, the researchers used documents that were mainly available on the webpages of the innovations. They were self-descriptions about the history and activities of the innovations, sometimes titled with the mission and vision or guiding principles and also yearly reports or funding applications. To conclude the array of methods, the researchers made field visits, partly in the course of conducting the interviews, and systematically documented them.

The transcripted interview material was as a first step openly coded; mostly using descriptive and concept coding (cf. Saldana, 2016). As a second step, the data was organized into categories and sub-categories in a code and category list, which was structured against the background of the research questions. This list served as a basis for the thematic analysis (cf. Bazeley, 2013; Kuckartz, 2013). The themes were related to the research focus and provided a basis for a theoretical understanding of the data (cf. Bryman 2012). Themes were generated for example by identifying patterns or trends in the data, repetitions, transitions, similarities, and differences regarding certain topics or questions in the interviews (Ryan \& Bernard, 2003; Bazeley, 2013). In this paper, the themes were declarative sentences used to describe the general character of ecosocial innovations.

\section{RESULTS AND DISCUSSION Case introduction}

Hirvitalo (FI-1), Tampere, Finland: Hirvitalo (Center of Contemporary Art Pispala) is a non-profit and open cultural space. Its aim is to stimulate local activities and enrich artistic and cultural life in the community. It was founded in 2006 by young local artists who squatted in the empty building. Nowadays, it is a registered association supported by the municipality of Tampere. Hirvitalo has weekly open meetings where participants and members can take part in planning and decision-making. It offers a range of activities from an open café and a social kitchen, to art exhibitions and gardening projects. All projects and activities are based on voluntary work by students, artists, and local people or on subsidized work for unemployed people.

Oma maa (FI-2), Helsinki area, Finland: Oma maa is an organic food cooperative and was founded around 2010. It is inspired by the concept of community-supported agriculture. The food is grown in the fields of an old farm, which is located $30 \mathrm{~km}$ from Helsinki. The cooperative has approximately 80-100 members, who pick up their weekly food bags directly from the farm or from the café that the cooperative also runs in Helsinki. Eight persons are at present so-called production-members, who actively take responsibility for the farming and food delivery. A big part of the work in Oma maa is done voluntarily by members; only during the summer months can the cooperative provide gainful employment for some farmers. 
Lapinlahden Lähde (FI-3), Helsinki, Finland: Lapinlahden lähde was initiated only 3 years ago when it rented an old hospital building in Helsinki. Now the building offers space for sustainable well-being and cultural events. The activities range from a vegetarian lunch café and art galleries to an old sauna and a small upcycling and second hand shop. Lapinlahden lähde also hosts many seminars and workshops. The association has four full time employees and a number of trainees and volunteers. One of their main aims is to create new jobs and offer paths to employment and meaningful work.

Kunst-Stoffe (GER), Berlin, Germany: Kunst-Stoffe is a registered association, which works in the fields of waste prevention and reduction, cultural development, and the promotion of creativity. Another important part is educational work. The main activity is to receive, organize, and store waste and second-hand material and to pass it to individuals or groups for further use. Apart from that, Kunst-Stoffe offers repair-cafés, a bike, and a wood workshop. It has approximately 15 persons who are active in its inner circle. Most of them are volunteers or freelancers; one person is part-time employed.

Velo (BE), Leuven, Belgium (Flanders): Velo has been established in the city of Leuven for more than 20 years. It is a social enterprise and part of the social economy in Flanders. It promotes bike mobility combined with re-use and re-cycle concepts. The main activities are repairing and renting bikes as well as mobile repair shops and other smaller bike projects. It also offers training for marginalized people; nowadays the majority are young people who often have a history of migration and refuge seeking. Velo offers 55 full-time jobs and has about 110 people working there, including volunteers and trainees.

Vinterra (IT), Mals, Italy (South Tyrol): Vinterra is a social cooperative that was founded 3 years ago. Its fields for growing organic vegetables are located in the valley of Vinschgau, which is close to the city of Merano. The main goal of the cooperative is to combine organic farming with a social agenda on a sound economic basis. In addition to the farming, Vinterra also runs a street kitchen and produces parfaits. It provides around 12 persons with gainful employment.

\section{Understanding the work of ecosocial innovations - results of the thematic analysis}

The above introduction segments have illustrated the great variety in the selected ecosocial innovations. This section presents the main results of the thematic analysis. The themes are mostly based on the similarities and differences between the statements of the interviewees, trends, and patterns as well as repetitions (cf. Ryan \& Bernard, 2003). It is understood that prior theoretical knowledge can also influence the formulation of themes. Furthermore, a theme is not always completely suitable for all cases. These impediments and variations are indicated in the theme descriptions as far as possible.

The following table shows the seven themes. They are to some extent self-explaining due to their form of declarative statements, but short descriptions are also presented to give the reader a better overview. The themes all provide answers to the main research questions. At this stage it did not seem helpful to allocate certain themes to certain aspects of the main or sub-questions. The themes disengage from the research questions. 


\begin{tabular}{|c|c|}
\hline Themes: & Short description: \\
\hline 1. From informal to formal & $\begin{array}{l}\text { All cases are organized in a specific legal } \\
\text { form even though some started as an informal } \\
\text { group or project. }\end{array}$ \\
\hline $\begin{array}{l}\text { 2. Creative mix of work, employment, } \\
\text { and engagement }\end{array}$ & $\begin{array}{l}\text { The ecosocial innovations use a variety of } \\
\text { different forms of work. Since new concepts } \\
\text { of work are decisive for social sustainability, } \\
\text { this is a crucial aspect of understanding the } \\
\text { functioning of ESI. }\end{array}$ \\
\hline $\begin{array}{l}\text { 3. Innovative due to the great } \\
\text { diversity in social practices }\end{array}$ & $\begin{array}{l}\text { The innovative potential of all cases cannot be } \\
\text { demonstrated by only one idea or solution of } \\
\text { an ecological and social problem and instead } \\
\text { by their great variety. }\end{array}$ \\
\hline $\begin{array}{l}\text { 4. Balancing all dimensions of } \\
\text { sustainability }\end{array}$ & $\begin{array}{l}\text { On an organizational level all innovations } \\
\text { combine social and ecological sustainability } \\
\text { in their missions and social practices even } \\
\text { though the people involved might only focus } \\
\text { on one aspect. }\end{array}$ \\
\hline $\begin{array}{l}\text { 5. Precarious existence as daily } \\
\text { routine }\end{array}$ & $\begin{array}{l}\text { The burden of a precarious existence affects } \\
\text { all ecosocial innovations. This has different } \\
\text { dimensions like a lack of funding, insecure } \\
\text { locations, or bureaucratic obstacles. }\end{array}$ \\
\hline $\begin{array}{l}\text { 6. Established relationships keep the } \\
\text { innovations running }\end{array}$ & $\begin{array}{l}\text { The external relationships with other civil } \\
\text { society actors or networks, public institutions, } \\
\text { or market actors are vital for all the ecosocial } \\
\text { innovations. }\end{array}$ \\
\hline $\begin{array}{l}\text { 7. Recognition, money, and time as } \\
\text { main resources }\end{array}$ & $\begin{array}{l}\text { The theme lists three important resources for } \\
\text { developing the work of ecosocial innovations } \\
\text { further. It delineates how the allocation of } \\
\text { these resources could be improved. }\end{array}$ \\
\hline
\end{tabular}




\section{From informal to formal}

All cases are organized in a legal form: they are registered associations (FI-1, FI-3, GE), (social) cooperatives (FI-2, IT), or an official social enterprise (BE). However, at the beginning not all of them were planning to use a legal form to organize. Literature about social innovations and SSE describes it as a common way of scaling up - out of informal and spontaneous initiatives often arise formal legal units with a clear structure (Elsen \& Schicklinski, 2016). Some of the ecosocial innovations still highlight their openness and creativity despite their legal form and the necessary structure (e.g., FI-1, FI-2, GE). This structure sometimes also guarantees a more inclusive organization with regular meetings and collective decisionmaking processes. The cooperatives and associations provide every member with one vote on important decisions of the organization. One active participant from Hirvitalo describes this with the emphasis on equality: "We have it so that if you are a member of the board or you are visiting first time the house you can vote when we make decisions" (FI-1/1).

In fact, not all participants, workers, or trainees are members of the associations or co-operatives even though they could become one. The active role matters more than official membership. All coordinators emphasize that everybody is still invited to the meetings and to contribute. For example, Velo aims at transparency and offers communication in all work places: "... we try to keep it on the level that everyone can participate. That's the biggest difficulty" $(\mathrm{BE} / 3)^{3}$. Even though they are all not for profit organizations, the degree of business-like structures is very different. Especially Velo, as a middle-sized social enterprise with many employees, and Vinterra, as a relatively young social cooperative with high expenses for the farming work, have to compete with other local market actors. The other cases are less involved in market structures.

\section{Creative mix of work, employment, and engagement}

It is not possible to understand the functioning of ecosocial innovations without understanding how work and employment are organized in these innovations. Social sustainability is after all strongly connected to new concepts of work and its organization (cf. Littig \& Grießler, 2005; Hildebrandt, 2003). However, the thematic analysis did not provide findings about completely new forms of employment. What is interesting in ecosocial innovations is the creative, or in some cases also chaotic, mix of various forms of work. The list of different forms of work (in a broad sense) is long. The active participants in ecosocial innovations can be part-time and full-time employees, trainees, freelancers, or volunteers (e.g., from the German national programs "Freiwillige soziale/ökologische Jahr"), or they can be part of subsidized employment promotion programs organized by different offices in the respective countries. With detailed descriptions, the list could be much more extended. In all cases, a large amount of civic engagement was crucial. It was based on a great passion to work for the mission and vision of the ESI and could be observed in all cases. In the two more market oriented cases - Velo and Vinterra - it is difficult to accept many volunteers. Velo stated that they wanted to pay everybody, and therefore they only have a low number of volunteers; Vinterra and Oma maa, both quite young cooperatives, have not enough resources to provide gainful employment over the whole year. The voluntary work is mostly done on the board of the cooperative and is necessary during harvest.

\footnotetext{
${ }^{3}$ The number after the case initials indicates the chronological order of the interviews.
} 
Constant full or part-time employment could only be financed by some of the ecosocial innovations out of their own profits or fundings (FI-3, BE, IT). The others had employees only for shorter periods of time or not at all. All of them used unemployment promotion schemes to run their practices, or from the other perspective, unemployed people already active in the ecosocial innovations benefited from these schemes by receiving income while working in the ESI. In some cases the employees and engaged people partly worked for their own subsistence. This could be observed in the two food related cooperatives Oma maa and Vinterra. Also, in the other cases interviewees worked to be able to use products or resources generated by the ESI for their own life (for example for mobility, own art projects, or leisure time). It is understood that the income situation of many of the interviewees and in general of people involved in the ecosocial innovations is precarious. Nevertheless, in some cases, the atmosphere of appreciation and mutual care in the working processes was considered as being more valuable than the salary. It was seen as the main difference when compared to for-profit organizations and as the innovative element of the ESI.

Overall, it is interesting to observe an ambivalent attitude toward the state and its institutions in the cases. They all use national or local programs for unemployed people and at the same time emphasize their independence and criticize the public institutions. All cases have a strong connection to the state actor - often not voluntarily. This could lead to benefits for the state institutions. As described above, the critical partnerships make the ecosocial innovations to be experts in certain fields. The members of ecosocial innovations are aware of all kinds of employment promotion programs, support schemes, and models of subsidized or voluntary work. Based on their experience and expertise, they could inform policy-makers about necessary changes for more sustainable forms of work.

\section{Innovative due to the great diversity in social practices}

As the case introductions have already partly revealed, all innovations have implemented more than one new (always related to the place and time) or alternative social practice and offer numerous products or activities. The innovative potential is most visible in this great variety in social practices. All cases could present a long list of activities that are already taking place or in the planning process. As one participant in Lapinlahden lähde mentions, "there is so much work to be done" (FI-3/1).

Every ESI started with more or less one problem or unmet need in focus. Thus, they originally aimed to propose an idea or solution to solve mainly that problem. In the case of Kunst-Stoffe, the collection points for leftover or second-hand material was the initial idea. The problem was the great amount of waste, and the unmet need affected people, at the beginning mostly artists, who needed and used the material. The idea was adapted from New York but was (and still is) innovative in Germany. However, Kunst-Stoffe did not stop there and further developed their fields of action. Despite scarce resources they nowadays run repair cafés in different districts of Berlin, they participate in urban gardening projects, they have a bike shop where people can assemble their own carrier bikes, and they have partly turned into an educational institution with strong connections to schools. Hirvitalo in Tampere first started due to the need of artists to have a gallery space, but since then the house has turned into a many-sided cultural center with ecological projects like permaculture, gardens, and a social kitchen. 


\section{Balancing all dimensions of sustainability}

Ecological aspects, and more concrete, ecologically sustainable alternative practices are important in all cases. Oma maa and Vinterra had naturally a clear vision of organic farming and an alternative food consumption on their agenda. In addition, they aimed to build a solidarity economy and support more equal social relationships. For example, one interviewee in Italy emphasized that "the combination of social, ecological and economic goals in a local circuit" is the innovative feature of Vinterra (IT/6) ${ }^{4}$. However, not only do the agricultural innovations grow vegetables as also others have gardening projects. The gardening provides locally grown food products but also offers meaningful activities for participants and increases wellbeing when people are in touch with nature (FI-1, FI-3, GE). In addition, the ideas of repair cafés and upcycling have obviously spread all over Europe. Velo is encouraging bike owners to repair their bikes at special repairs stations, but also Kunst-Stoffe, Hirvitalo, and Lapinlahden lähde have integrated the idea into their activities. Kunst-Stoffe is not only aiming at waste reduction and re-use processes but also offers educational workshops about re-using and enhances the community building at the same time. Another example are social kitchens, some of which serve vegan food made partly from food waste ingredients. They bring people together, alleviate loneliness and separation, and also promote ecological sustainability. Often the meals are offered at a very low price so that even people with a low income can afford them. These examples readily demonstrate how the ESIs are able to balance the ecological and social as well as often the economic and cultural dimensions of sustainability.

However, not all of the cases had a strong or explicit ecological approach from the beginning. They might not be considered as ecological innovations at first sight, even though they aimed to promote alternative art, sustainable well-being, or more sustainable employment possibilities. On a personal level, most of the participants share the values of sustainability, but some of them focus mainly on social or cultural aspects of sustainability. For some, the reduced use of natural resources is a nice and pleasant side effect, while others have a special field of interest within the activities of the organizations and leave the ecological projects to others. Overall, on an organizational level all ecosocial innovations can be described as wanderers between the various dimensions of sustainability.

\section{Precarious existence as daily routine}

The reality of a precarious existence, regarding certain social practices but also on some occasions the innovation as a whole, is familiar to all cases. The term precarious is nowadays mostly used in relation to income and employment (e.g., della Porta et al. 2015), but in general the term precarious is often taken as a synonym for insecurity. The difficult financial situation, the struggle for funds, and the constant question about how to pay bills (and salaries) was described in almost all interviews. Some felt that there is a big problem to get funds due to their multi-faceted activities and the lack of a clear status in the eyes of the authorities (GER, FI-1, FI-3). The ecosocial innovations were not considered as nature protection organizations, established art centers, social enterprises or as official educational organizations. This caused difficulties to put them into a category that would be helpful for getting funds.

\footnotetext{
${ }^{4}$ The authors of the paper conducted the English translations of the interview quotations.
} 
A big issue is also the precarious situation of location (FI-1, FI-3, GER). Often, the ecosocial innovations can use old houses or rooms, and in some occasions with subsidized rental contracts. Sometimes the old buildings are in need of renovation, like in the case of the house used by Hirvitalo or in the case of one of the storage places used by Kunst-Stoffe. They do not have a heating system for example. In both cases it is impossible to apply for money for the renovation, even if the work would be done by people from the ESI, since the rental contracts can be discharged at almost any time. Therefore, what the organizations need is better security for planning.

Another big structural obstacle is with the general bureaucracy. In some cases (FI-1, FI-2, IT), it was characterized as a great burden for the functioning of the cooperatives and associations. It is not only time consuming but can even put members of the board in difficult positions. Small mistakes regarding book keeping or the organization of work can make them criminally liable.

In short, missing support from the municipalities or national authorities is hindering the development of the innovations. It is an issue that all cases in the field of social economy seemingly have to face (cf. Cook, Smith, \& Utting, 2012). Politicians at the local level would praise the activities and even award prizes to them, but afterwards all suggestions for improvement were unheard or promises for support stayed vague (GER, FI-1, FI-3). Others claim that the further away the responsible people are situated, for example the regional or national government, the harder it is to be heard. They would not fully understand the importance of the work, or other powerful parties are impeding any improvements (BE).

\section{Established relationships keep the innovations running}

All cases have established networks that enable their work, promote their development, or secure their existence. These networks include close relationships with administrations, authorities, and other actors of the social and solidarity economy. Despite the problems many interviewees described with public bodies like unemployment centers or social services, sometimes fruitful relationships could be established at the same time (GER, BE, IT, FI-3). There were numerous testimonies of good practices. For example, when one interviewee from Velo talks about their cooperation with the municipality: "The local offices know what we do. They come here, they see it. We ask them to have their meeting here instead of the city hall location because we think it is important they see what we do. It works very good. That is no problem. If we have an idea, they always listen and try to help and solve and combine things." (BE/3). In addition, good relationships with other actors in the same field or with wider networks are crucial. In all cases interviewees describe these relationships. For example, Oma maa offers its restaurant space for like-minded groups to hold events. Kunst-Stoffe is part of the association of open workshops where members not only exchange information and ideas but also support each other practically for example by sharing open software.

\section{Recognition, money, and time as main resources}

Many interviewees stipulated a better recognition of the work and the achievements of ecosocial innovations (e.g., GER, FI-1, FI-3). All interviewees had suggestions about how to promote their organizations or improve their practices. The proposals, ideas, and concrete steps for improvements are manifold. Some interviewees also suggested taking their model and using it elsewhere by referring to the idea of scaling up their ecosocial innovations. Establishing the collection points for waste material run by Kunst-Stoffe in two districts of Berlin is one example. They could be easily established in all districts of Berlin as an obligatory part of a new culture of sustainability; next to repair cafés and urban gardening projects, as one interviewee suggested (GER/2). Other actors in cooperation with KunstStoffe could provide them, but again the political will to support it and a concrete plan to implement it would be needed. So far, it seems that neither of them exist. 
Regarding the scarce resources of time and money, the interviewees wished they could receive more long-term security. It should also be easier to find people who would benefit from employment promotion programs and work in the organizations for a longer period. However, it was assumed that promoting and financing social projects like social cooperatives is not so popular among politicians. It would have no political priority and would not be suitable for the political "market" (IT/1). The realm of finances and funds is certainly another big issue. In most cases it is not so much about direct financing but more about making it easier for every ESI to operate in the long run. The short-term lack of resources can seriously hinder the development as is described in the case of Oma maa: "Our dream has been that the restaurant would make enough profit so that we could employ people to take care of morning shifts. It is like with the chicken or the egg, that first the restaurant should work in order to be profitable so that we could pay salaries. But how to get it running if we don't have..." (FI$2 / 3)$.

The challenges with resources can concern buildings and rooms but also the lack of social programs for volunteers and unemployed people. Velo for example would like to offer more training for young former refugees. A lack of financing and other obstacles, for example language requirements from the social administration, are making it impossible to hire young people with only a basic knowledge of Dutch. Some need years to reach the required language level and during that time they are not allowed to work. In the end, often all three aspects - better recognition, easier access to financial resources, and available time for development - go hand in hand.

\section{CONCLUSIONS AND OUTLOOK}

The aim of the paper was to gain knowledge about the work and the significance of ecosocial innovations. The seven themes presented in this article can be viewed as a list of characteristics, describing what ecosocial innovations do and how they do it, what their challenges are, and what should be changed to support their development further. The results of the thematic analysis have also provided evidence of numerous similarities between the cases. All ecosocial innovations integrate the five core elements of social innovation (cf. Caulier-Grice et al., 2012), which are enriched with the fulfillment of not only social needs but also ecological needs: 1) "Novelty" - all cases introduced a new ecosocial idea or solution related in their city or region; 2) "From ideas to implementation" the idea or solution was successfully implemented or realized; 3) "Meets a social need" - the social practices of all ESI are primarily aiming at meeting social needs of individuals or groups in their city or region; 4) "Effectiveness"- the successful work of the ESI is effective in different ways, usually by realizing the ideas and solutions with scarce resources; and 5) "Enhances society's capacity to act" - the effects at the local level are visible in many ways, for example by building relationships, improving the use of resources, and developing capabilities. The case studies link what is often missing when social innovations are examined and discussed: Social innovations can also promote the human-nature relationship. Their focus is not limited to human needs and social relationships between individuals or groups but can be widened to relationships between people and their natural environment.

The presentation of the themes has further delineated how the cases are embedded in social and solidarity economy. This is another aspect of social innovation discussions, which is often missing. All innovations fulfill the criteria listed in the basic definition of SSE provided by Wallimann (2014). They are organized in different legal forms and differ immensely in their size and role in the community. Some do not create jobs and stay on purpose at the rim of the city. Yet, they all still share a lot of common ground. The core characteristics of civil society actors in the field of social and solidarity economy, like participation and self-organization, are for example clearly visible in the characteristics of the ESI (cf. Elsen \& Schicklinski, 2016). 
All that remains is a brief reflection on the practice and theory of social work and ecosocial innovations. Understanding ESI means understanding better how social and ecological problems are interconnected and how sustainability can be operationalized at a local level. There is much to learn for a profession that seems to currently struggle with its role and responsibilities regarding sustainability. If social work finally accepts the interconnectedness of social and ecological problems, and its part of the responsibility for solving these, then an active role is not one option but a necessity. For social work practitioners the social practices put into action by ecosocial innovations could for example serve as models for their organizations or as possible partners at the local level. Topics for further research include how and what to learn from the pioneering work of ESI as well as exploring the connections between ecosocial innovations and social policy. 


\section{REFERENCES}

Bazeley, P. (2013). Qualitative data analysis. Practical strategies. London: Sage.

Bryman, A. (2012). Social research methods (Fourth Edition). Oxford: University Press.

Caulier-Grice, J., Davies, A., Patrick, R., \& Norman, W. (2012). Defining social innovation. A deliverable of the project: "The theoretical, empirical and policy foundations for building social innovation in Europe" (TEPSIE), European Commission - 7th Framework Programme, Brussels: European Commission, DG Research. Retrieved from http://siresearch.eu/sites/ default/files/1.1\%20Part\%201\%20-\%20defining\%20social\%20innovation_0.pdf

Coates, J., \& Gray, M. (2012). The environment and social work: An overview and introduction. International Journal of Social Welfare, 21(3), 230-238. doi: 10.1111/j.14682397.2011.00851.x

Cook, S., Smith, K., \& Utting, P. (2012). Green economy or green society? Contestation and policies for a fair transition. (Occasional Paper No.10. Social Dimensions of Green Economy and Sustainable Development). Retrieved from http://www.unrisd.org/80256B3C005BCCF9/ search/B24EA25289BD528AC1257AC5005F6CA5

Della Porta, D., Hänninen, S., Siisiänen, M., \& Silvasti, T. (2015). The precarization effect. In D. della Porta, S. Hänninen, M. Siisiänen, \& T. Silvasti (Eds.), The new social division: Making and unmaking precariousness (pp. 1-23). New York: Palgrave.

Dominelli, L. (2012). Green social work. From environmental crises to environmental justice. Cambridge: Polity Press.

Dominelli, L. (2014). Promoting environmental justice through green social work practice: A key challenge for practitioners and educators. International Social Work, 57(4), 338-345. doi: $10.1177 / 0020872814524968$

Elsen, S. (2016). Community based economy and ecosocial transition. In A.-L. Matthies \& K. Närhi (Eds.), Ecosocial transition of society. Research on the contribution of social work and social policy (pp. 54-70). Oxford: Routledge.

Elsen, S., \& Schicklinski, J. (2016). Mobilising the citizens for the socio-ecological transition. In T. Sauer, S. Elsen, \& C. Garzillo (Eds.), Cities in transition. Social innovation for Europe's urban sustainability (pp. 221-238). New York: Routledge.

Fichter, K. (2010). Nachhaltigkeit: Motor für schöpferische Zerstörung? In J. Howaldt \& H. Jacobsen (Eds.), Soziale Innovation. Auf dem Weg zu einem postindustrielle Innovationsparadigma (pp. 181-198). New York: Springer.

Flick, U. (2011). Triangulation. Eine Einführung. Wiesbaden: Springer. 
Flyvbjerg, B. (2006). Five misunderstandings on case-study research. Qualitative Inquiry, 12(2), 219 245. Retrieved from http://journals.sagepub.com/doi/pdf/10.1177/1077800405284363

Gibson-Graham, J.K. (2008). Diverse economies: Performative practices for 'other worlds'. Progress in Human Geography, 32(5), 613-632. Retrieved from http:/communityeconomies.org/site/assets/ media/Gibson/Diverse\%20Economies\%202008.pdf

Gismondi, M., \& Cannon, K. (2012). Beyond policy “Lock-In”? The social economy and bottomup sustainability. Canadian Review of Social Policy, 67, 58-73. Retrieved from http://crsp.journals. yorku.ca/index.php/crsp/article/view/35371

Hargreaves, T., Longhurst, N., \& Seyfang, G. (2013). Up, down, round and round: Connecting regimes and practices in innovation for sustainability. Environment and Planning A, 45, 402-420. doi: $10.1068 / \mathrm{a} 45124$

Haxeltine, A., Avelino, F., Wittmayer, J., Kemp, R., Weaver, P., Backhaus, J., \& O’Riordan, T. (2013). Transformative social innovation: A sustainability transitions perspective on social innovation. Retrieved from http://kemp.unu-merit.nl/pdf/Haxeltine\%20et\%20al.\%202013\%20TSI\%20 Transition\%20Perspective.pdf

Hildebrandt, E. (2003). Arbeit und Nachhaltigkeit. Wie geht das zusammen? In G. Linne \& M. Schwarz (eds.), Handbuch Nachhaltige Entwicklung. Wie ist nachhaltiges Wirtschaften machbar (pp. 381-393)? Opladen: Leske+Budrich.

Howaldt, J., Kopp, R., \& Schwarz, M. (2015). Social innovations as drivers of social change: Exploring Tarde's contribution to social innovation theory building. In A. Nicholls, J. Simon, \& M. Gabriel (Eds.), New frontiers in social innovation research (pp. 29-51). Hampshire: Palgrave.

Kemp, S. (2011). Recentring environment in social work practice: Necessity, opportunity, challenge. British Journal of Social Work, 41(6), 1198-1210. doi: 10.1093/bjsw/bcr119

Kuckartz, U. (2013). Qualitative text analysis. A guide to methods, practice and using software. London: Sage.

Lee, E., Mishna, F., \& Brennenstuhl, S. (2010). How to critically evaluate case studies in social work. Research on Social Work Practice, 20(6), 682-689. doi: 10.1177/1049731509347864

Littig, B., \& Grießler, E. (2005). Social sustainability. A catchword between political pragmatism and social theory. International Journal of Sustainable Development, 8(1/2), 65-79. Retrieved from http:// www.ihs.ac.at/pdf/soz/test2.pdf

Matthies, A.-L., \& Närhi, K. (2017). Ecosocial transition of society. Research on the contribution of social work and social policy. Oxford: Routledge. 
McKinnon, J., \& Alston, M. (2016). Ecological social work. Towards sustainability. Hampshire: Palgrave.

McNeill, J. (2013). Enabling social innovation: Opportunities for sustainable local and regional development. Retrieved from http:/www.communityeconomies.org/site/assets/media/ JoanneMcNeill/JMcNeill_Social-Frontiers-2013_enabling-social-innovation.pdf

Mehmood, A., \& Parra, C. (2013). Social innovation in an unsustainable world. In F. Moulaert, D. MacCallum, A. Mehmood, \& A. Hamdouch (Eds.), The international handbook on social innovation: Collective action, social learning and transdisciplinary research (pp. 53-66). Cheltenham, UK: Edward Elgar.

Moulaert, F., MacCallum, D., Mehmood, A., \& Hamdouch, A. (2013). General introduction: The return of social innovation as a scientific concept and a social practice. In Authors (Eds.), The international handbook on social innovation: Collective action, social learning and transdisciplinary research (pp. 1-6). Cheltenham, UK: Edward Elgar.

Murray, R., Caulier-Grice, J., \& Mulgan, G. (2010). The open book of social innovation. Retrieved from http://www.nesta.org.uk/sites/default/files/the_open_book_of_social_innovation.pdf

Närhi, K., \& Matthies, A.-L. (2016). Conceptual and historical analysis of ecological social work. In J. McKinnon \& M. Alston (Eds.), Ecological social work. Towards sustainability (pp. 21-38). Hampshire: Palgrave.

Nicholls, A., \& Murdock, A. (2012). The nature of social innovation. In Authors (Eds.), Social innovation: Blurring boundaries to reconfigure markets (pp. 1-30). Basingstoke, UK: Palgrave Macmillan.

Olson, P., Moore, M.-L., Westley, F. R., \& McCarthy, D. D. P. (2017). The concept of the Anthropocene as a game-changer: A new context for social innovation and transformations to sustainability. Ecology and Society, 22(2), 31. doi.org/10.5751/ES-09310-220231

Parra, C. (2013). Social sustainability: A competing concept to social innovation? In F. Moulaert, D. MacCallum, A. Mehmood, \& A. Hamdouch (Eds.), The international handbook on social innovation: Collective action, social learning and transdisciplinary research (pp. 142-154). Cheltenham, UK: Edward Elgar.

Peeters, J. (2012). The place of social work in sustainable development. Towards ecosocial practice. International Journal of Social Welfare, 21(3), 287-298. doi: 10.1111/j.1468-2397.2011.00856.x

Ragin, C., \& Becker, H. (1992). What is a case? Exploring the foundation of social inquiry. Cambridge: University Press.

Ryan, G.W., \& Bernard, H.R. (2003). Techniques to identify themes. Field Methods, 15, 85-109. doi: https://doi.org/10.1177/1525822X02239569 
Saldana, J. (2009). The coding manual for qualitative researchers. London: Sage.

Schiederig, T., Tietze, F., \& Herstatt, C. (2012). Green innovation in technology and innovation management: An exploratory literature review. R \& D Management, 42(2), 180-192. doi: 10.1111/j.1467-9310.2011.00672.x

Science Communication Unit, University of the West of England, Bristol (2014). Science for Environment Policy In-depth Report: Social Innovation and the Environment. Retrieved from http:// ec.europa.eu/environment/integration/research/newsalert/pdf/IR10_en.pdf

Utting, P. (2015). Introduction: The Challenge of scaling up social and solidarity economy. In P. Utting (Ed.) Social and solidarity economy. Beyond the fringe (pp. 1-37). London: Zed Books.

Van Kemenade, T., \& Teixeira, A. A.C. (2017). Policy stringency and (eco)-innovation performance: A cross country analysis. Journal on Innovation and Sustainability, 8(2), 34-60. doi.org/10.24212/2179$3565.2017 \mathrm{v} 8 \mathrm{i} 2 \mathrm{p} 34-60$

Wallimann, I. (2013). Environmental policy is social policy - Social policy is environmental policy: Toward Sustainability Policy. New York: Springer.

Wallimann, I. (2014). Social and solidarity economy for sustainable development: Its premises - and the Social Economy Basel example of practice. International Review of Sociology, 24(1), 48-58. doi: $10.1080 / 03906701.2014 .894345$

Yin, R. K. (2014). Case study research. Design and methods (Fifth Edition). London: Sage. 